\title{
EUROPEAN NEIGHBOURHOOD POLICY, A POLISH PERSPECTIVE
}

\author{
Paula Marcinkowska ${ }^{1}$ \\ University of Warsaw
}

\begin{abstract}
:
Before the bing-bang enlargement of the EU in 2004, the Union needed to define a coherent policy towards its new neighbours. The European Neighbourhood Policy was formulated when Poland became a member of the EU. Due to its close ties with the Eastern European countries, Poland tried to shape the EU foreign policy towards its neighbouring countries and became their advocate in Brussels. In 2009 it succeeded in establishing the Eastern Partnership as one of the dimensions of the European Neighbourhood Policy.
\end{abstract}

\section{Resumen:}

Antes de que tuviera lugar la gran ampliación de la UE en 2004, la Unión necesitaba definir una política coherente con respecto a sus vecinos. La Política de Vecindad Europea se formuló cuando Polonia se intregó en la UE. Dadas sus estrechas relaciones con los estados de Europa del Este, Polonia trató de contribuir a la formulación de la politica exterior de la UE hacia sus estados vecinos y ser su defensor en Bruselas. En 2009 consiguió la aprobación de la Asociación Oriental como una de las dimensiones de la Política Europea de Vecindad.

Palabras clave: Unión Europea, Polonia, política exterior, Política Europea de Vecindad, Asociación Oriental, estados vecinos, miembros de la UE, actor regional.

\section{Copyright (C) UNISCI, 2016.}

Las opiniones expresadas en estos artículos son propias de sus autores, y no reflejan necesariamente la opinión de UNISCI. The views expressed in these articles are those of the authors, and do not necessarily reflect the views of UNISCI

\footnotetext{
${ }^{1}$ Paula Marcinkowska is professor of Law and International Institutions, Institute of International Relations University of Warsaw

E-mail: p.marcinkowska@uw.edu.pl.

http://dx.doi.org/10.5209/rev_RUNI.2016.n40.51804
} 


\section{Introduction}

The EU enlargement in 2004 not only expanded the European integration proccess to ten new members, but also influenced the priorities and approaches of the EU foreign policy. Due to geographical, historical, economic, and cultural ties between Poland and the new EU eastern neighbours. Warsaw tried to shape the EU's foreign policy towards its neighbouring countries. The europeanization of eastern issues became the core point of Polish advocacy in the Union ${ }^{2}$. Warsaw declared its wish to be the advocate of Eastern Europe in Brussels ${ }^{3}$ and saw its EU membership as an incentive for the regional development. Despite the fact that Poland was not an EU member when the European Nieghbourhood Policy (ENP) was formulated, it made a significant contribution to the debate on the eastern dimension of the EU foreign policy.

The article does not focus on bilateral relations between the EU and/or Poland and its neighbours, but presents a comprehensive approach to the neighbouring countries. The author explains the European Neighbourhood Policy from the Polish perspective, stressing those aspects and dimensions that have been emphasized by Polish authorities through the whole period of its activities in Brussels. The main research question concerns the Polish impact on a real shaping of the EU eastern policy and enhancing relations between the Union and the Eastern European countries.

\section{European Neighbourhood Policv: Assumptions:}

The European Neighborhood Policy and the enlargement process were launched simultaneously in 2004. Due to the forthcoming accession of ten countries, Brussels needed to elaborate a coherent policy towards its new neighbours. As it could not promise the membership in the EU, it wanted to be attractive enough for promoting deeper cooperation with non-member states.

In August 2012, as a response to the invitation from the General Affairs Council addressed to the High Representative and Commission to present a proposal of a new framework of relations with the neighbours, Javier Solana (High Representative of Common Foreign and Security Policy) with Christophen Patten (EU Commissioner), issued a letter entitled "Wider Europe". The aim of this initiative was to respond to the new challenges that the EU was facing: to prevent the creation of new dividing lines in Europe due to the big bang enlargement, and to find an adequate answer to the needs and threats emerging from the new neighbourhood. The effect of consulations between the EU institutions brought the formulation of the European Neighbourhood Policy with the main task of ensuring a ,ring of friends" and priviliged relations with the closest neighbours of the EU. ${ }^{4}$ The ENP objective has been defined as "avoiding the emergence of new dividing lines between the enlarged EU and its neighbours and instead strengthening the prosperity, stability and security of all." ${ }^{5}$ It has been emphasized that the ENP is based on such values as: democracy, respect of human rights, and the rule of law. The European Neighbourhood Policy was disigned covering 16 neighbouring countries. From East: Ukraine, Moldova, Belarus, Georgia, Armenia, Azerbaijan; and South: Morocco, Algeria, Tunisia, Libya, Egypt, Israel, Jordan, Lebanon,

\footnotetext{
2 Pomorska, Karolina, "The Impact of Enlargement: Europeanization of Polish Foreign Policy? Tracking Adaptation and Change in the Polish Ministry of Foreign Affairs", The Hague Journal of Diplomacy, 2 (2007), p. 25-51.

${ }^{3}$ Brussels is used here as a synonym for the European Union.

${ }^{4}$ Communication from the Commission, European Neighborhood Policy, Strategy Paper $\{$ SEC(2004) 564, 565, 566, 567, 568, 569, 570\}, $\operatorname{COM(2004)~} 373$ final, Brussels 12.05.2004.

${ }^{5}$ ENP website: http://eeas.europa.eu/enp/about-us/index_en.htm
} 
Syria and the Palestinian Authority. (Belarus, Libya and Syria do not fully participate in the structures of the ENP, due to its domestic situation and non-compliance with the core values promoted by the Union). ${ }^{6}$

The idea of the ENP assumes the use of different types of mechanisms on both the intergovernmental and supranational level - foreign policy and economic tools (with a major role of the European Commission in the latter case). All these instruments were tools for helping neighboring countries in their transformation processes and improve security, stability and prosperity in the region. This had to be achieved by allowing neighboring countries the use of a wider range of EU tools, without providing assurances on a future membership. "Everything but institutions" approach presented by the former President of the European Commission, Romano Prodi, had clashed with the expectations of those neighbours that wanted to apply for the EU membership in the near or distant future. The reason is that the Union does not give them any long-term "awards" (such as membership in the accession process) for compliance with the EU rules and principles. Higher expectations of some of the eastern neighboring countries that were present since the launching of ENP, together with Polish advocacy for closer cooperation with the East European states, have been a starting point for a debate on the revision of the new policy that could take into consideration the need for creating separate regional dimensions of the EU policy.

\section{Poland and the East}

Both, enlargement process and the new EU approach towards its neighbours have become a challenge for Polish foreign policy. After joining the EU, this challenge became a very demanding task, given the fact that Poland had been pursuing an active foreign policy with the countries of Eastern Europe that now were covered by the new European Neighbourhood Policy. This situation required the design of a new strategy establishing a link between EU's interests and the priorities of Polish foreign policy. ${ }^{7}$

Polish perspective on the ENP should derive from its eastern policy. The latest was rooted not only in the historical ties with the closest neighbours, but also linked to the concepts of reconciliation between Poland and the Eastern European countries, concepts and ideas developed by Polish intellectuals Jerzy Giedroyc and Juliusz Mieroszewski in the Parisian journal "Kultura". ${ }^{8}$ Notwithstanding, due to the muliplicity of countries in the postSoviet area, Poland has separate policies for each of its neigbours. The strategic partner in the East is Ukraine. Important relations are with Belarus (though bilateral relations are limited), Russia, Moldova and South Caucasus states (their importance have grown in recent years in particular in the context of energy security). ${ }^{9}$ These foreign policy priorities have influenced Polish activities in the context of the EU foreign policy. Although Poland has been very active in promoting the need for a consistent EU policy towards its eastern neighbours, Warsaw did not present a coherent vision of its strategy towards a new EU neighbourhood policy (there is not a single document on the Polish strategy towards the ENP). The obstacle could be seen in the coincidence with the accession preparations, as Poland, having an observer status before

\footnotetext{
${ }^{6} \mathrm{http}: / /$ eeas.europa.eu/enp/about-us/index en.htm

Marzęda-Młynarska, Katarzyna, "Strategia polityki zagranicznej Polski wobec Europejskiej Polityki Sąsiedztwa" in Pietraś, Marek; Stachurska-Szczesiak, Katarzyna; Misiągiewicz, Justyna (eds.) (2012), Europejska Polityka Sasiedztwa Unii Europejskiej, Lublin Wydawnictwo Uniwersytetu Marii CurieSkłodowskiej, p. 349.

${ }^{8}$ See: Pomianowski, Jerzy (2004): Na wschód od zachodu. Jak być z Rosją?, Warszawa, Rosner\&Wspólnicy.

9 Szeptycki, Andrzej, "A new phase of Polish messianism in the East?" in Bieleń, Stanisław (ed.) (2011): Poland's Foreign Policy in the 21st Century, Warsaw, Difin, pp. 293-294.
} 
joining the EU, couldn't formally influence the outcome of discussions on the European Neighbourhood Policy, but needed to adapt the new EU policy once it became a full member after the accesion on the 1st of May 2004. Nevertheless, Poland since late 90s. has not been hiding its aspirations to build a new European policy towards Eastern Europe. For Poland, this region has been of particular interest due to geographical proximity, historical, economic and cultural ties. It has been also a strategic region taking into consideration security issues (including energy security and migration challenges). ${ }^{10}$ When Polish border has become the external border of the EU, Warsaw's aspirations to influence the Union's foreign policy towards its neighbouring countries have gained in importance. Secure neighbourhood has been of interest of the whole European Union. ${ }^{11}$ Poland, through its ties with the region wanted to be seen an advocate of Eastern Europe in Brussels. The threat of creating new dividing lines (just as the "iron curtain" in the cold war) in Europe after the $2004 \mathrm{EU}$ enlargement, encouraged Poland to take more concrete steps in its committment to the Union's eastern policy. The promotion of a secure neighbourhood in the EU has been in line with the Polish national security strategy, as well as a result of the two track approach in the Polish foreign policy after 1989, which presupposes maintaing good relations both with USSR and the comunist republics in Europe (later Russia and the Eastern European countries). As a consequence of this policy, Poland has seen the EU policy towards its neighbours as a tool in helping to ensure a safe and stable Eastern Europe. ${ }^{12}$

\section{Polish Initiatives towards Eastern Neighbours}

When the ENP was in the process of consultation, Poland, as we said, was not yet a member of the EU, but it was invited to give its opinion only in the last phase of the policy formulation (but with no voting rights). Polish position regarding the European Neighbourhood Policy was directly linked to its foreign policy priorities. It means, on one hand, good relations with the Western neighbour (Germany), on the other, developing relations with the Eastern European countries: Ukraine, Belarus, Moldova and also Russia. Poland had the ambition to become a bridge between East and West. ${ }^{13}$

In this vein, Poland attempted to influence the EU policy towards the Eastern Europe in the Eastern Dimension of the Common Foreign and Security Policy (CFSP). Poland's aspirations could be seen in 1998, when Bronisław Geremek, the foreign minister, in his speech inaugurating accession negotiations, expressed Polish willingness to contribute to shape the EU policy towards the eastern neighbours. ${ }^{14}$ Włodzimierz Cimoszewicz (Polish foreign affairs minister) in his speeches since 2001 also emphasized the fact, that Poland is developing "good-neighbourly relations with all its eastern neighbours" and underlined readiness to share Poland's experience of political transformation with its eastern partners. ${ }^{15}$ This issue was then developed in a non-paper on the EU eastern policy prepared and presented by Poland in January $2003^{16}$ (and expanded in May 2003 as a proposal titled "New

\footnotetext{
${ }^{10}$ Marzęda-Młynarska, Katarzyna, et al., op. cit., p. 350-351.

${ }_{11}$ A secure Europe in a better world, European Security Strategy, Brussels 12 XII 2003.

${ }^{12}$ Marzęda-Młynarska, Katarzyna, et al., op . cit., p. 352-353.

${ }^{13}$ Nervi Christenses, Alessandra (2010): The Making of the European Neighbourhood Policy, Nomos, p. 116117.

14 Piskorska, Beata, "Partnerstwo Wschodnie 2011. Sukces czy porażka polskiej prezydencji w Unii Europejskiej" in Legucka, Agnieszka (ed.) (2012): Polska prezdencja wobec wyzwań współczesnej Unii Europejskiej, Warszawa, Difin, p. 157-158.

${ }^{15}$ Nervi Christenses, Alessandra, op. cit., p. 118-119.

${ }^{16}$ Non-paper z polskimi propozycjami w sprawie przyszłego ksztaltu polityki rozszerzonej UE wobec nowych wschodnich sąsiadów, Ministerstwo Spraw Zagranicznych Rzeczypospolitej Polskiej, styczeń 2003, www.msz.gov.pl
} 
Neighbours, a framework for relations"). ${ }^{17}$ Poland's proposal reflected its vision regarding the EU policy towards the neighbouring countries. Warsaw agreed with the conclusion of the Kopenhagen Council summit in December 2002, stating that the EU enlargement creates an opportunity to "upgrade" relations with eastern neighbours. Poland saw the need to diversify relations with neighbours depending on their aspirations in deepening cooperation with the EU, their progress with internal reforms and its alignment with the European norms and policies. According to the Polish proposal, it was advisable to create a coherent eastern dimension that will require a specific approach for each country. This integrated policy was to be based on three pillars: community (within Common Foreign and Security Policy), governmental (both on bilateral and multilateral level), and non-governmental. ${ }^{18}$ It was assumed to be supplementary (and not competetive) to the already existing northern dimension $^{19}$ (it was seen as a blueprint for the Polish proposal). Moreover, according to Poland, future integration of Ukraine into the European structures lies in the interest of the whole EU. The project envisaged cooperation also with Belarus, Moldova nad Russia to intensify political dialogue with these countries, and enhance people-to-people contacts. Poland also proposed extending EU programmes of assitance to the eastern neighbours in their transformation processes, and wished to contribute to the EU's eastern policy. ${ }^{20}$

Polish idea did not succeed at that time on the EU level, due to a couple of factors: law requirements enbedded in the eastern policy, lack of Russia's presence in the project (Moscow was seen by most of the "old" EU members as a crucial partner in the east) and a not strong enough position of Poland in the EU. ${ }^{21}$ Poland was not familiar with all the proceedings (particularly informal ones) applied in Brussels. Thus it did not know how to play "the Brussels game" and all its actions were taken through the formal channels. ${ }^{22}$ Nevertheless, its proposal refered, among other suggestions, to the creation of a"European space of political and economic co-operation within the Wider Europe", and this particular recommendation could be seen in a first concept of new neighbourhood, proposed two months later by the European Commission which became the basis for the European Nieghbourhood Policy. $^{23}$

Just before the final version of the ENP was agreed, Poland did not express its clear position on the project. The ambiguity of the Polish attitude was linked to the changes made in the original proposal, which was directed only to Eastern Europe. During the negotiations on the content of the ENP, under pressure of Spain and France, its coverage was extended to the Mediterranean neighbours and Southern Caucasus states. ${ }^{24}$ Polish delegation showed a clear disappointment regarding the whole policy, and issued an unilateral statement saying that "the ENP should not prejudge developing further long term relationship between

\footnotetext{
${ }^{17}$ Cieszkowski, Andrzej, "Polityka rozszerzonej Unii Europejskiej wobec wschodnich sąsiadów - wkład Polski" in Wizimirska, Barbara (2004): Rocznik Polskiej Polityki Zagranicznej 2004, Warszawa, Akademia Dyplomatyczna MSZ, p.105.

${ }_{18}$ Non-paper z polskimi propozycjami... op.cit.

${ }^{19}$ A joint policy between EU, Russia, Iceland and Norway - launched in 1999, renewed in 2006.

${ }^{20}$ Non-paper z polskimi propozycjami... op.cit.

${ }^{21}$ Kaczmarski, Marcin (2009): Polska polityka wschodnia na tle polityki wschodniej Unii Europejskiej. Czyli Europa idzie na Wschód (po 2005 roku), Monitoring Polskiej Polityki Zagranicznej, Warszawa, Centrum Stosunków Międzynarodowych., p. 21.

${ }^{22}$ Pomorska, Karolina, „Poland. Learning to play Brussels game" in Wong, Reuben; Hill, Christopher (eds.) (2011), National and European Foreign Policies. Towards Europeanization, Routledge, p. 175.

${ }^{23}$ Communication from the Commission to the Council and the European Parliament: Wider Europe Neighbourhood. A new framework for relations with our Eastern and Southern neighbours, Brussels, 11.3.2003, COM (2003) 104 final.

${ }^{24}$ Szczerbiak, Aleks (2012): Poland within the European Union. New akward partner or new heart of Europe?, London and New York, Routledge, p. 86.
} 
European new neighbours and the EU". ${ }^{25}$ When the document establishing the ENP was issued, ${ }^{26}$ Poland did not express enthusiasm for the main policy assumptions, as the final concept of the ENP differ from the Polish proposals in the case of geographical content and the lack of a main goal: the membership perspective. The criticism was related mainly to the lack of diversification between regions (east and south), in the context of their differences as well as aspirations to the EU accession. ${ }^{27}$ It should be noted here that the European Neighborhood Policy does not eliminate the possibility of the EU membership, but at the same time it does not promise a future enlargement. The exclusion of Turkey and the Western Balkans in the ENP confirms that.

Despite the fact that Poland was not fully satisfied with the final document establishing the ENP, it had to accept the new policy framework when joining the EU. At the same time, Warsaw's promotion of the eastern policy in Brussels strengthened the need of Europeanization of its foreign policy priorities. Poland's belief in the EU power in the region (notably when taking into account Poland's tense relations with Russia) has helped Warsaw in being more active in advocating a common approach to Eastern Europe. Through its involvement in the EU foreign policy, Poland wanted to strengthen its position within the Union and become one of the leaders in the process of formulating the eastern policy. ${ }^{28}$ Therefore, since the beginning of its activities in the European structures, Poland has been engaged with shaping the eastern dimension of the EU foreign policy. Warsaw's attempts to be a leader in this policy have its roots in the Poland's historical and transformative experience and aspirations to be perceived as a regional power. Poland has been focusing on promoting democracy, security, stability and economic development in Eastern Europe. All this became the main goals of the ENP itself. To make it happen, it offered assistance in exporting its transformation experience to the neighbouring countries, preventing Russia's domination in the region, and also advocating the EU further enlargement to the east (mostly Ukraine). ${ }^{29}$

\section{ENP - Polish Assumptions:}

We can emphasize two main assumptions of the Polish strategy regarding the European Neighbourhood Policy:

- $\quad$ There is too much diversity among neighbouring countries for developing relations within one common framework, the ENP;

- There is a crucial difference between eastern and southern neighbours, as they have different expectations and aspirations towards cooperation with the EU. ${ }^{30}$

From the beginning, Polish involvement in the EU foreign policy meant an attempt to include in the agenda an "open doors" policy for the eastern partners. ${ }^{31}$ Although this idea was not reflected in the final conception of the ENP, Poland has not given up trying to convince the

\footnotetext{
${ }^{25}$ European Neighbourhood Policy, draft Council conclusions, Statement by Polish delegation, Council of the European Union 10292/04, Brussels 10 June 2004, at http://register.consilium.europa.eu/doc/srv?l=EN\&f=ST\%2010292\%202004\%20ADD\%201.

${ }^{26}$ Communication from the Commission, European Neighbourhood Policy, Strategy Paper \{SEC(2004) 564, 565, 566, 567, 568, 569, 570\}, COM(2004) 373 final, Brussels 12.05.2004.

${ }^{27}$ Piskorska, Beata, "Partnerstwo Wschodnie 2011". op. cit., p. 158-159.

${ }^{28}$ Szczerbiak, Aleks, op. cit., p. 87.

${ }^{29}$ Ibid., p. 84.

${ }^{30}$ Marzęda-Młynarska, Katarzyna, op. cit., p. 354

${ }^{31}$ Ibid.
} 
rest of Europe on the need to make a distincion between those who aspire to become an EU member (Eastern European countries), and those from North Africa and the Middle East (neighbours of Europe) who are not European countries and according to the EU law cannot apply for the EU membership.

Polish authorities have been supporting further enlargement of the Union to the east. It reflects the main goal of the eastern policy promoted by Poland, avoiding the creation of

division lines in Europe. Relations with particular neighbours were to be dependent on their progress in implementing reforms and aspirations concerning their cooperation with the EU. According to Poland, clear perspectives of membership for Ukraine and Moldova (countries most interested in their future accession to European structures) can only mobilize them towards closer relations with the European Union, and help the Union answer to their European integration aspirations."Old member states" were, however, not willing to offer concrete accession perspectives to the eastern countries within the neighbourhood policy. Thus the concept of the ENP remained focused on the creation of a "ring of friends" with closer economic cooperation with the Union. ${ }^{32}$ This kind of cooperation could be enhanced, but (so far) the EU cannot and does not want to offer any other long-term goal for its neighbours,."everything but institutions", nothing more.

After the biggest enlargement of the EU, all relations between Union and its eastern neighbours were conducted through the new European Neighbourhood Policy. Brussels was, however, criticized for not being effective towards particular countries (such as Belarus or Ukraine) or territorial conflicts (ex. Transsnistria). Warsaw saw the opportunity to fill the gap created by the ENP shortcomings, offering its experience in the transformation processes of the eastern countries, proposing new solutions in the face of the ineffectiveness of the EU actions towards its neighbouring region. ${ }^{33}$

Nevertheles, political changes in the neighbourhood had an impact on the changes of relations between the EU and its eastern neighbours and supported the Polish advocacy of Eastern Europe in Brussels. The Orange Revolution in Ukraine brought the belief in the proeuropean direction of the country and its interest in deeper relations with the EU. However, as Dariusz Milczarek argues, "one could even have an impression that in fact most EU Member States principally intended to maintain correct relations with Moscow and that they were ready to even sacrifice democratization of Ukraine to that priority. (This was especially evident in the attitude assumed by France). ${ }^{134}$ Nonetheless, at that time the EU was busy with its own institutional crisis and internal reforms, and was not ready to offer anything more than the ENP. Ukraine, as well as other eastern neighbours were treated in the same way as other (southern) neighbours of Europe, according to"one-size-fits-all policy", the main assumption of the ENP (which later was considered insufficient due to the assymetry of interests and expectations between the EU and their neighbours).

Deeper relations with Ukraine, and its integration within the European structures has been a key objective of the "eastern policy" promoted by Polish authorities. Poland was the first country that oficially recognized in 1991 the independence of Ukraine, and became an advocate of its interests in Brussels. Integration of Ukraine within the European structures was not only seen as important factor for the Polish security strategy, but also as a way of reducing Russia's zone of influence in the nearest neighbourhood.

\footnotetext{
${ }^{32}$ Cieszkowski, Andrzej, op. cit., pp. 106-108.

${ }^{33}$ Pomorska, Katarzyna, op. cit., p. 175.

${ }^{34}$ Milczarek, Dariusz:: "Eastern Dimension of the European Union's Foreign Policy", Yearbook of Polish European Studies, 10/2006, p. 20.
} 
The Orange Revolution open a window of opportunity for Polish activism in the EU foreign affairs. Polish President, Aleksander Kwaśniewski, succeded to engage the High Representative of CFSP, Javier Solana into negotiations in the post-election conflict. Poland played a role of mediator, and contributed to the adoption of the Action Plan towards Ukraine. ${ }^{35}$ Hereby, it has become a crucial participant in the internal EU debate on the type of cooperation with the eastern partner. Nevertheless, diverse visions of Ukraine in Europe are in many cases derived from different perceptions of East Europe (with Russia as the main partner). Many countries do not see any possibilities to enhance cooperation with Kiev without the improvement of relations with Russia. ${ }^{36}$ Besides, only Poland and Lithuania saw Ukraine's application to the EU as a priority. Western countries, such as France, were against further enlargement, others, like the UK, focused on Turkish application. As Aleks Szczerbiak noted "Poland was perhaps the most committed and enthusiastic pro-enlargement member state in the enlarged EU". For Poland, the ENP was not the framework for the inclusion of Ukraine's aspirations. Warsaw believed that managing to have it closer to the EU, the Union would have no other choice than to offer the status of member to Ukraine. ${ }^{37}$

Besides strenghtening relations with Ukraine, Poland has been striving for improving relations with Belarus. Polish position on relations with Minsk is however unclear, as it offcially disaproves Lukashenka's regime, but at the same time sees the need to maintain formal contacts with Belarusian authorities, and support pro-democratic opposition (twintrack policy). Poland is pursuing a more active EU policy towards regime change. The Union decided the implementtion of various restrictions (ex. ban on visas), but still keeps Belarus away from the use of the majority of the tools and mechanisms available within the ENP.

Poland supports also the Moldova's EU aspirations and its internal transformation processes. According to Poland, a democratic and economically developed Moldova could contribute to the stability in the region and ensure a more secure neighbourhood for Poland and the European Union. Therefore, Poland supported all the initiatives that could lead to strengtening relations between Brussels and Chisinau, including peacefull settlement of the Transnistria conflict. $^{38}$

The South Caucasus is however perceived by Poland mostly in terms of economics reasons and as an energy link (Nabucco gas pipeline). Poland strongly supported Georgia in its war with Russia in 2008 and advocates a stronger cooperation between Tbilisi and the EU within the Eastern Partnership. In spite of all, Polish interests regarding Georgia, Armenia and Azerbaijan, are different from the ones manintained with its closest neighbours. For Poland economic and humanitarian aid are the main priority in the South Caucasus case. ${ }^{39}$

What Poland has underestimated in its lobbing for the EU eastern policy, is the fact that Western countries have perceived Eastern Europe from the perspective of the global cooperation with Russia, as the main, and most influential partner in the region. Relations between the European Union and its eastern neighbours are based on competition with Russia for influence in the region. Despite this important fact, Moscow refused to participate in the European Neighbourhood Policy (relations EU-Russia are based on a"strategic partnership"),

\footnotetext{
${ }^{35}$ Nervi Christenses, Alessandra, op. cit., pp. 124.

${ }^{36}$ More: Barburska, Olga:"Polska wobec europejskich aspiracji Ukrainy" in Borkowski, Jan (ed.) (2006), Rola Polski $w$ kształtowaniu polityki wschodniej Unii Europejskiej na przykładzie Ukrainy, Warszawa, Centrum Europejskie Uniwersytetu Warszawskiego.

${ }^{37}$ Szczerbiak, Aleks, op. cit., p. 88-91.

${ }^{38}$ Kosienkowski, Marcin: "Polska a Mołdawia i Naddniestrze", Rocznik Instytutu Europy Środkowo-Wschodniej 10, no.1 (2012), pp. 1-4.

39 Dudek, Adriana:"Partnerstwo Wschodnie i polski interes narodowy" in Nadolska, Jadwiga; Wojtaszczyk, Konstanty A. (eds.) (2010): Polska prezydencja w Unii Europejskiej, Warszawa, ASPRA-JR, pp. 293-295.
} 
it influences political decisions of the neighbouring countries. ${ }^{40}$ Polish main goal in Brussels, when lobbing for the EU eastern policy, was thus to covince countries like France and Germany to develop relations with Russia in the EU framework, rather than at the bilateral level. $^{41}$ As a result of this involvement in the eastern neighborhood, the Polish bilateral relations with Moscow deteriorated, as the policies promoted by Poland clash with Russia's interests in the region. ${ }^{42}$ Bilateral relations have been improved when the new government in Poland took office (2007). Easing of tensions between Warsaw and Moscow (in 2008, Poland withdrew its veto in the EU negotiations of the new agreement with Russia), helped Poland gain a reinforced position within the EU, when promoting a stronger eastern partnership.

\section{The Eastern Partnership}

The European Neigbourhood Policy was created as an instrument for the promotion of EU interests and values as well as to strengthen the position of the Union as an effective international actor. ${ }^{43}$ Nonetheless, the adoption of the ENP in 2004 did not diminish the goals and interests of particular EU states, and is constantly critisized and even qualified as inefficient for the promotion of the EU influence in the neighbourhood. Different priorities and foreign policy directions have resulted in the creation of different subregional dimensions within the ENP.

The European Nieghbourhood Policy is mainly a bilateral policy. ${ }^{44}$ Different regional initiatives: Union for the Mediterranean (UfM, 2008), the Black Sea Strategy (BSS, 2008) and the Eastern Partnership (EaP, 2009) complement already existing bilateral tools of cooperation ensured by the ENP, such as Partnership and Cooperation Agreements (a new type of Association Agreements has already been signed with Ukraine, Moldova, and Georgia) with the eastern countries, and Association Agreements with the North African and Middle East states; plus Action Plans or Association Agendas, and Country Reports.

The concept of Eastern Partnership has been partially an answer to the failure of the previous proposal: the eastern dimension of the CFSP, and at the same time a response to other regional dimensions within the foreign policy framework - as an added value to the Black Sea synergy ${ }^{45}$ and Northern dimension, and a counterbalance to the Union for the Mediterranean. ${ }^{46}$ Both, Black Sea Synergy ${ }^{47}$ and Union for the Mediterranean ${ }^{48}$ have been launched as a part of the ENP framework, although BSS is addressed not only to the Eastern

\footnotetext{
${ }^{40}$ In 2011, Wladimir Putin presented a new integration project for Euroasia, with the aim of creation Euroasian Union, based on the customs union between Russia, Belarus and Kazakhstan. Its establishmenet was to ensure a strong position of Russia in the Eastern Europe. More: Adomeit, Hannes, „Putin's Euroasian Union": Russia's integration project and policies on Post-Soviet space", Neighbourhood policy paper, CIES Kadir Has University and The Black Sea Trust for Regional Cooperation of the German Marshall Fund, no. 04, Istanbul\&Bucharest July 2012.

${ }^{41}$ Szczerbiak, Aleks, op. cit., pp. 95-96.

${ }^{42}$ Longhurst, Kerry; Zaborowski, Marcin (2007): The New Atlanticist. Poland's Foreign and Security Policy Priorities, The Royal Institute of International Affairs Chatham House, Blackwell Publishing Ltd, p. 61.

${ }^{43}$ Kapuśniak, Tomasz: "Unia Europejska wielu wymiarów - wprowadzenie" in Borkowski, Paweł J.; DośpiałBorysiak, Katarzyna; Kapuśniak, Tomasz (2009): Wymiar południowy, północny i wschodni Unii Europejskiej: osiagnięcia, szanse, wyzwania, Lublin-Łódź-Warszawa, Prace Instytutu Europy Środkowo-Wschodniej, p. 10.

${ }^{44} \mathrm{http}$ ://eeas.europa.eu/enp/about-us/index en.htm

45 Communication from the Commission to the Council and the European Parliament on Black Sea Synergy. A New Regional Cooperation Initiative, Brussels 11. 04. 2007, COM(2007)160 final.

${ }^{46}$ Kaczmarski, Marcin, op. cit., p. 22.

${ }^{47}$ Armenia, Azerbaijan, Bulgary, Greece, Georgia, Moldova, Russia, Romania, Turkey, Ukraine.

${ }^{48}$ Joint Declaration of the Paris Summit for the Mediterranean, Paris, 13 July 2008, http://ufmsecretariat.org/wpcontent/uploads/2012/09/ufm_paris_declaration1.pdf
} 
ENP countries in the Black Sea region, but also to Russia (strategic partnership) and Turkey (accession policy), states that are not part of the ENP framework. Due to the fact that BSS and EaP were both addressed to the eastern countries, initially there were concerns over a possible competition between two EU projects (although they have different aims: EaP: deeper integration with the EU; BSS: dealing with challenges emerging only from the Black Sea region). ${ }^{49}$

The biggest challenge Poland was facing when preparing the Eastern Partnership project was to gain acceptance and support from other EU members. It was not enthusiastically accepted by all EU countries. As a reuslt, not all European leaders were present at the launching summit in Prague in 2009. ${ }^{50}$ Initially, even the Commissioner responsible for external relations and the ENP, Benita Ferrero-Waldner was afraid of the duplication of existing structures (EaP vs. Black Sea Strategy). Equally cautious was Angela Merkel, who at the beginning was more engaged with the Black Sea Synergy project than interested in the Polish proposal. ${ }^{51}$ Russian intervention in Georgia in 2008 was a crucial factor in the awakening of the Western EU members. They realized the importance of releasing the region from the Russian influence. The war in Georgia had thus a direct impact on the support for the Eastern Partnership by the Western EU members (like France), that were not interested in deepening relations with the Post-soviet space. The tense situation in the Caucasus "forced" the EU countries to draft a concrete cooperation proposal for the eastern neighbours to bring them closer to the EU structures. ${ }^{52}$

The Eastern Partnership project was presented for the first time by the Polish foreign affairs minister, Radosław Sikorski, at the EU meeting of foreign ministers in April 2008 (shortly after the French proposal to create the Union for Mediterranean as a Southern dimension of the ENP). The proposal was previously carefully prepared and consulted with the EU institutions and member states. The concept was offcially submitted, as a joint proposal of Poland and Sweden called "Eastern Partnership" at the European Council summit in June 2008. Its aim was to strenghten eastern dimension of the ENP. ${ }^{53}$ The European Council concluded in March 2009 (2 months before the EaP project was launched) that "promoting stability, good governance and economic development in its eastern neighborhood is of strategic importance for the European Union. In line with the Commission communication of 3 December 2008, the European Council welcomes the establishment of an ambitious Eastern Partnership conclusions". ${ }^{54}$

The EaP was formally launched at the Prague summit on the 7th of May 2009. It has been addressed to 6 eastern partners (covered by the ENP): Ukraine, Moldova, Belarus, Georgia, Armenia and Azerbaijan. The EaP differs from other ENP dimensions, as it put emphasis on the convergence with the EU rules and standards (Union for the Mediterranean

\footnotetext{
49 Popielawska, Joanna, „W jakim towarzystwie? Partnerstwo Wschodnie na tle innych inicjatyw UE na wschodzie", Analizy natolińskie, no. 5(37) 2009, p. 19.

${ }^{50}$ Examples of European leaders, who did not participate in the Eastern Partnership launch summit in Prague: UK, Spanish and Italian prime ministers and French President.

51 Kamińska, Joanna:"Rola Polski w budowaniu wschodniego wymiaru Europejskiej Polityki Sąsiedztwa: Partnerstwo Wschodnie" in Fiszer, Józef M., (ed.) (2012): Europejska Polityka Sasiedztwa Unii Europejskiej. Geneza, doświadczenia, perspektywy, Warszawa, Dom Wydawniczy Elipsa, pp. 279-280.

52 Świeboda, Paweł; Sadowska, Maria, Wschodnie Partnerstwo - dobry początek, sukces dopiero będzie, http://www.demoseuropa.eu/index.php?option=com content\&view=article\&id=254\%3Awschodniepartnerstwo--dobry-pocztek-sukces-dopiero-bdzie\&Itemid=95\&lang=pl

${ }^{53}$ Kapuśniak, Tomasz (2010): The eastern dimension of the European Union's Neighbourhood Policy. Inclusion without membership?, Warszawa, Centrum Europejskie Natolin, p. 90-91.

54 Brussels European Council, 19/20 March 2009, Presidency Conclusions, Council of the European Union, Brussels, 29 April 2009, 7880/1/09 REV 1, at

http://www.consilium.europa.eu/uedocs/cms_data/docs/pressdata/en/ec/106809.pdf
} 
focused on regional projects). The Partnership offers two levels of cooperation: bilateral and multilateral. The first one is based on concluding Asssociation Agreements (already signed with Ukraine, Moldova and Georgia), establishing Deep and Comprehensive Free Trade Areas and liberalizing the visa-regime, with the aim of establishing a visa-free system. Multilateral cooperation is focused on four thematic platforms:

1. Democracy, good governance, stability;

2. Economic integration together with convergence with other Union's policies;

3. Energy security;

4. People-to-people contacts. ${ }^{55}$

In addition this thematic cooperation, flagship initiatives have been launched to help eastern countries fulfill their bilateral goals. They relate to: border management, small and medium seized enterprizes, natural and man-made disasters, energy efficiency, and promotion of good environmental governance. ${ }^{56}$ Poland supports closer cooperation with the Eastern European states by promoting a democratic transformation as well as the integration with the EU market. Implementation of the acquis communautaire by the EaP countries is seen by Warsaw as a tool in creating good investment environment which plays an important role in the economic relations with the region. ${ }^{57}$ Poland is looking for a flexible approach to visa liberalization process, supports stronger EU commitments to conflict prevention in the region, cultural cooperation and civil society movements (with special focus on Civil Society Forum as a platform of non-governmental organizations from partner countries and EU member states). It encourages promotion of the EU in neighbouring countries. These aims are being implemented not only by Polish government, but also by non-governmental organisations which are present in the neighbouring countries. ${ }^{58}$ Poland strived also to increase financial aid to Eastern Europe, as it was underfinanced comparing to the instruments designed for the Southern neighbourhood. During negotiations on the EU financial framework for 2007-2013, member states adopted the financial rule which assumed distribution of two-thirds of available funds to the countries of North Africa and Middle East, and one third to the eastern partners. ${ }^{59}$ Poland, as it previously did when the Eastern Partnership was launched, suggested equal opportunities for all the neighborhood countries, in the South and East and finally the EU decided to allocate additional EUR 600 milion (EUR 350 million as new allocations, and EUR 250 million redistributed from regional cooperation) in the 2010-2013 financial framework to the eastern neighbours. Financial assistance to the EaP countres covered also additional resources, such as loans from the European Bank for Reconstruction and Development and the European Investment Bank. ${ }^{60}$

\footnotetext{
${ }^{55}$ Ministry of Foreign Affairs, Republic of Poland - Eastern Partnership, at http://www.msz.gov.pl/en/foreign_policy/eastern_partnership/

${ }^{56}$ Ibid.

${ }^{57}$ Kaca, Elżbieta; Łada, Agnieszka, "Partnerstwo Wshodnie - polska perspektywa", Biuletyn niemiecki, No. 6, 13.05.2010, p. 10 .

${ }^{58}$ Cieszkowski, Andrzej, op. cit., pp. 109-111.

${ }^{59}$ Czerny, Inga, "Nowy problem w UE - finansowanie Partnerstwa Wschodniego", 20.02.2009, at http://forsal.pl/artykuly/114817,nowy problem_w_ue finansowanie partnerstwa_wschodniego.html

${ }^{60}$ Kapuśniak, Tomasz (2010): "The eastern dimension...", op. cit., p. 94.
} 


\section{Partners in the EU:}

The European Union's foreign policy is characterized by diverse visions and interests of all 28 member countries. Therefore, effectiveness of the Polish strategy towards the ENP relies on finding partner countries within the EU, which have similar aims and interests. ${ }^{61}$

Before 2004 (EU enlargement and The Orange revolution in Ukraine), most of the EU activities towards the east were focused on relations with Russia. In the face of the new enlargement, Russia and the European Union needed to answer common challenges in shaping the post-Soviet space. After joining the EU and the creation of the ENP, Poland gained new partners in its efforts towards intensification of relations with eastern neighbours beyond Russia first policy. As we said, when the new neighbourhood policy was in the process of ellaboration within the EU insitutions, Poland with other Central and Eastern European countries were not part of the EU structures yet. Despite their different foreign policy cultures, they all shared the same goals (besides integration into the European structures), in particular developing good neighbourly relations. ${ }^{62}$ Poland, therefore, made attempts to use the already existing frameworks of regional cooperation, such as the Visegrad Group (Poland, Czech Republic, Slovakia, Hungary). ${ }^{63}$ The V4 presented many "joint declarations" on cooperation with the Eastern European countries, nevertheless, regarding the ENP, the strongest voice of the Visgerad Four was seen in the August 2007 document presented to the Council "The Visegrad Group Contribution to the discussion on the strengthening of the European Neighbourhood Policy". The paper supported the Polish and Lithuanian response to the German "ENP Plus" proposal. ${ }^{64}$ The core message of the V4 was that a clear differentiation between eastern and southern neighbours within the European Neighbourhood Policy was needed. ${ }^{65}$ Besides Visegrad Group countries, the need to enhance cooperation with the Eastern Europe was also expressed by the Baltic states, mainly Lithuania (as stated above), but also Latvia and Estonia. ${ }^{66}$ Moreover, the role of Scandinavian states in promoting EU eastern policy should not be underestimated. Thanks to the support of Sweden ("old" member of the Union, balancing the anti-russian perception of Polish foreign policy), the concept of the Eastern Partnership gained approval at the EU arena. However, the necessity to gain support from "old" member states in pursuing a more active policy towards Eastern Eutrope was inevitable. One of the first "old" countries which favored the eastern cooperation was Austria, which came with a proposal of common energy policy, that require dialogue with Ukraine and Belarus. ${ }^{67}$ Germany, as one of the main players in Europe, with its strong economic position, and its willingess to be engaged in Eastern Europe, have become a crucial partner for Poland in pursuing the EU Eastern policy. ${ }^{68}$ For many years, German

\footnotetext{
${ }^{61}$ Marzęda-Młynarska, Katarzyna, op. cit., p. 359.

${ }^{62}$ Nervi Christenses, Alessandra, op. cit, p. 114.

${ }^{63}$ Known also as "Visegrad Four" or "V4". It was formed in 1991 as a group of 3 countries: Czechoslovakia, Poland, Hungary. In 1993, due to disintegration of Czechoslovakia, both successors - Czech Republic and Slovakia have become members of the V4.

${ }^{64}$ The aim of the German concept named "ENP-Plus" in 2007 was to create more attractive partnership to the neighbouring countries to ensure stable and secure EU neighbourhood.

${ }^{65}$ Dangerfield, Martin, "The Visegrad Group in the Expanded European Union: From Pre-accession to Postaccession cooperation", East European Politics \& Societies, Summer 2008, volume 22, no 3, p. 653.

${ }^{66}$ Walak, Marta, „Od Europejskiej Polityki Sąsiedztwa do Partnerstwa Wschodniego - nowy dyskurs w dyplomacji UE" in Legucka, Agnieszka (ed.) (2012): Polska prezdencja wobec wyzwań wspótczesnej Unii Europejskiej, Warszawa, Difin, pp. 151.

${ }^{67}$ Walak, Marta, op. cit., p. 151.

${ }^{68}$ Kempe, Inge, „The German Impact on the European Neighbourhood Policy" in Overhaus, Marco; Maull, Hanns W. ; Harnisch, Sebastian (eds.), The New Neighbourhood Policy of the European Union. Perspectives from the European Commission, France, Germany, Poland, Ukraine and Moldova, Foreign Policy in Dalogue, vol. 7, issue 19, Ask-Europa Stiftung, Trier, July 27, 2006, p. 26.
} 
strategy towards the east was based on the "Russia first policy", which arised from personal relations between leaders of Germany and Russia, Helmut Kohl and Boris Yeltsin, and later Gerhard Schröder and Vladimir Putin. This had a direct impact on the controversial decision of Germany on the Nord Stream project with Russia, the pipeline construction under the Baltic sea, that was taken in spite of objections from Poland, and other "new" member states. $^{69}$

Angela Merkel, as a new chancellor, has not shown the same fascination for Russia, as her predecessors, and emphasizes the need for a more effective European Neighbourhood Policy, which makes her a good partner for Polish efforts concerning the EU eastern policy. Chancellor Merkel has introduced a more "balanced" Ostpolitik to the hard "Russia first policy". Still its core element are good relations with Kremlin (though more pragmatic as before) but taking into account the security in the region, as well as the interests of the Eastern European countries. German proposal of the "ENP Plus" promoted during its presidency in the Council in 2007 confirms that. Later on, Germany supported the Polish-Sweden proposal of the Eastern Partnership to deepen cooperation with the eastern neighbours, but still avoid any type of declarations regarding the membership perspectives of these countries, as well as establishment of a visa-free area (although chancellor Merkel supported a visa facilitation regime). ${ }^{70}$

\section{The Polish Presidency in the Council of the EU (2011). The Promotion of the Eastern Partnership}

The Eastern Partnership was promoted in and outside Union during the Polish presidency in the Council of the EU (July-December 2011). Poland argued that good relations with Russia and other countries from the region are in the interest of the whole EU, also in economic terms. The goals for the EaP during its presidency were focused on the finalization of Association Agreements and negotiations of Deep and Comprehensive Free Trade Areas with Ukraine and Moldova; enhanced cooperation on the visa liberalization process; discussion on new type of relations with Belarusian authoritities, as well as bilateral cooperation between the EU and Russia. ${ }^{71}$ Overall assesment of the Polish presidency should be positive, although Poland did not manage to succeed in all its goals (the bigest failure was the lack of progress in relations with Belarus). Political crisis in the Southern neighbourhood of the EU dominated the Brussel's agenda in this period of time, but Poland managed to draw attention to Eastern Europe in the times of political turbulences in the North Africa nad the Middle East. As a response to the Arab Spring in the Southern neighbourhood, as well as the tense situation in Belarus, Polish foreign minister, Radosław Sikorski initiated, the European Endowment for Democracy $^{72}$ as a tool allowing for a rapid response to the needs emerging from the neighbourhood (both South and East). The new tool was accepted by other EU countries in December 2011.

\section{Conclusion}

We can consider The European Neighbourhood Policy as the best instrument the EU could offer to its neighbours after the biggest enlargement in 2004. Hhowever it lacks proper tools

\footnotetext{
${ }^{69}$ Marcinkowska, Paula, „Republika Federalna Niemiec wobec wschodniego wymiaru Europejskiej Polityki Sąsiedztwa", Studia Politica Germanica 2012/1 (1), p. 123.

${ }^{70}$ Gotkowska, Justyna:"Niemcy wobec Partnerstwa Wschodniego", Komentarze OSW, no. 37, 17.06.2010.

${ }^{71}$ Piskorska, Beata, „Partnerstwo Wschodnie 2011... op.cit., p. 171.

${ }^{72}$ European Endowment for Democracy https://www.democracyendowment.eu/
} 
that could enable a solid response to the fast changing political environment, both in the south, as well as in the east.

The core of the ENP is the system of interdependence. The European Neighbourhood Policy is based on the "hub-and-spoke" model, which assumes correlation between its different dimensions (including cooperation between Brussels and partner countries), and common general objectives common for all neighbours. ${ }^{73}$ Though the ENP is different from the enlargement policy, eastern neighbours are more willing to accept the EU rules (comparing to the countries from the North Africa and the Middle East) and some of them present membership aspirations. Cooperation with eastern neighbours, is nevertheless more challenging when observing the enlargement fatigue in the EU and the lack of accession perspectives offered to the close neighbours.

Definitely none of the "old" EU countries can understand better the eastern neighbours than its "new" members. Poland decided to take advantage of its potential in that task. The goal of the Polish diplomacy within the EU was to convince other members that neighbours have diverse interests towards the Union, therefore different types of cooperation should be implemented for the southern and eastern countries. The establishment of the Eastern Partnership has to be seen as a success for the Polish diplomacy, even if not all goals have been achieved. Poland managed to systematize EU relations with its eastern neigbours, as the general concept of the ENP was considered to be insufficient for developing closer relations with the east. Poland has succeeded in increasing its position in the decision-making process regarding eastern neighbours and raised the significance of Eastern Europe (particularly Ukraine) to the EU. It has also contributed to the change the perceptions on Russia among "old" member states, being more critical, and to perceive the region beyond the Russia first policy. ${ }^{74}$ Polish diplomacy had also an impact on the evolution of thinking on Eastern Europe among the EU members. It managed to convince the Union to develop a more enhanced cooperation with this region, although the Ukrainian membership was not defined, one of the strategic goals of Polish activity within the EU foreign policy.

Germany remains the closest partner for Poland in pursuing its vision of the eastern policy, particularly since its Ostpolitik has not only been focused on Russia but also on Eastern European countries, covered by the ENP. Cooperation with France in Eastern Europe is of limited importance. In order to win the French vote for the new eastern policy, Warsaw supported the project of the Union for Mediterranean (proposed by France in 2008) as a "bargain" for approval of the EaP. The change in the French foreign policy could be seen after Nicolas Sarkozy became President. Since then, France has become active in relations with the Eastern European countries, (and not only with Russia). ${ }^{75}$ This was however dictated almost entirely by political aspirations to co-shape the EU foreign policy and counterbalance the German dominance in this matter.

The consequences of the political events in the Southern neighborhood also have an impact on the effectiveness of the Eastern Partnership, as they affected the foreign policy preferences of particular member states and the whole Union. ${ }^{76}$ The impact could be seen in the redistribution of financial aid towards the EU neighbours.

\footnotetext{
${ }^{73}$ Marcinkowska, Paula (2011): Europejska Polityka Sasiedztwa. Unia Europejska i jej sąsiedzi - wzajemne relacje $i$ wyzwania, Warszawa 2011, p. 9.

${ }^{74}$ Kaczmarski, Marcin, op. cit., p. 25-26.

75 Ibidem, p. 4-5.

76 Starzyk-Sulejewska, Joanna, „Partnerstwo Wschodnie jako element stosunków zewnętrznych Unii Europejskiej" in Żołędowski, Cezary (ed.) (2012), Polska Prezydencja w Radzie Unii Europejskiej. Wybrane zagadnienia w perspektywie politologicznej i medialnej, Warszawa, Instutut Polityki Społecznej Uniwersytetu Warszawskiego.
} 
The EU international relations in Eastern Europe are of special importance to the security of the continent. They have become complicated and dangerous due to the unstable situation in Ukraine. Poland should continue its efforts towards strengthening the cooperation between the EU and its eastern neighbours. The emphasis should be put on Ukraine, as its interests with the country converge with those of the EU - trade, energy security, and, in particular, security. In the face of major challenges emerging from the eastern EU border, it seems to be crucial for the EU to offer a more enhanced cooperation to counterbalance the Russian dominance in the region.

Poland has been engaged in the resolution of the Ukrainian crisis. Radosław Sikorski, as minister of foreign affairs, participated, together with his German and French counterparts in the negotiations with the leaders of the Maidan protests in Ukraine in February 2014. ${ }^{77}$ Although this peace deal was not implemented, Poland played a significant role in pursuing the Ukrainian case on the EU table.

The European Neighborhood Policy was not sufficient for dealing with the fastchanging political environment and sudden threats emerging from the neighborhood, such as the Arab Spring and Russian annexation of Crimea. Due to the lack of tools that the EU could use to respond to new challenges, the Union should decide on a comprehensive revision of its policy towards neighboring countries. The inclusion of the membership perspective in the ENP goals for countries that fulfill accession criteria is advisable as it could encourage eastern countries to more enhanced cooperation with the EU. Taking into account Polish ties with the eastern neighbours, its achievements in promoting the region in Brussels, and willingness to be perceived as a regional power, Poland, with the help of other partners in the EU, will continue to play a crucial role in strengthening relations between the EU and its eastern neighbours.

\footnotetext{
77 Easton, Adam:"Poland's crucial role as Yanukovych's rule crumbled", BBC News, 25 February 2014, http://www.bbc.com/news/world-europe-26342882
} 